\title{
Lectotypification of the Linnaean name Dianthus virgineus (Caryophyllaceae) and its taxonomic consequences
}

\author{
Gianniantonio Domina, ${ }^{1}$ (D) Giovanni Astuti, ${ }^{2}$ (D) Giulio Barone, ${ }^{1}$ (D) Domenico Gargano, ${ }^{3}$ (D) Luigi Minuto, ${ }^{4}$ (i) \\ Lucia Varaldo ${ }^{4}$ \& Lorenzo Peruzzi ${ }^{5}$ (i) \\ 1 Department of Agricultural, Food and Forest Sciences, University of Palermo, Viale delle Scienze ed. 4, 90128 Palermo, \\ Italy \\ 2 Botanic Garden and Museum, University of Pisa, Via Ghini 13, 56126 Pisa, Italy \\ 3 Department of Biology, Ecology and Earth Sciences, University of Calabria, Loc. Polifunzionale, 87030 Arcavacata di Rende \\ (Cosenza), Italy \\ 4 Department for the Earth, Environment and Life Sciences (DISTAV), University of Genoa, Corso Europa 26, 16132 Genova, \\ Italy \\ 5 Department of Biology, University of Pisa, Via Derna 1, 56126 Pisa, Italy \\ Address for correspondence: Lorenzo Peruzzi, lorenzo.peruzzi@unipi.it
}

DOI https://doi.org/10.1002/tax.12563

\begin{abstract}
A lectotype is designated for the name Dianthus virgineus. The relationships between $D$. virgineus, D. caryophyllus var. caryophyllus, and D. caryophyllus var. inodorus are analyzed. Dianthus virgineus is the oldest available name that applies to a species complex that is often referred to as $D$. sylvestris or a broad circumscription of the cultivated ornamental D. caryophyllus. The taxonomic consequences are discussed, and the need for further studies is highlighted.
\end{abstract}

Keywords Linnaean names; Mediterranean Basin; nomenclature; taxonomy; typification

\section{INTRODUCTION}

Dianthus L. is the second-largest genus in Caryophyllaceae after Silene L., with species occurring across Africa, Asia, Europe, and North America (Mabberley, 2008). Globally, 349 species are currently accepted (WFO, 2021). Most of these species are concentrated in the Mediterranean region, and, according to Marhold (2011), 234 species occur in Europe and the Mediterranean area. One of the most taxonomically challenging species complexes in this genus is that of D. sylvestris Wulfen, a name described in 1786 (Wulfen, 1786) and neotypified by Bacchetta $\&$ al. (2010). Recently, Tison \& Foucault (2014) used the name D. caryophyllus L. for this same species complex.

Reviewing the oldest names within this group, we came across those described by Linnaeus, in particular the name Dianthus virgineus L. (Linnaeus, 1753), which remains untypified. Here, we typify $D$. virgineus and discuss its relationship to $D$. caryophyllus L. var. caryophyllus and D. caryophyllus var. inodorus L. in the light of previous typifications by Jafri \& El-Gadi (1978) and Langen \& al. (1984). This study is part of an ongoing project aimed to advance taxonomic knowledge of selected genera of the Italian flora, by an integrated approach (Giacò \& al., 2021).

\section{MATERIALS AND METHODS}

The protologue of Dianthus virgineus (Linnaeus, 1753: 412) was studied to inform the search for original material, also taking advantage of Jarvis (2007). High-resolution digital images from LINN and UPS were consulted. Typification follows the International Code of Nomenclature for algae, fungi and plants (Shenzhen Code, Turland \& al., 2019, ICN hereafter). After the nomenclatural study, based on the type localities of $D$. virgineus and $D$. caryophyllus var. inodorus, we carried out fieldwork, sampling topotype populations for both names. Twenty individuals of $D$. virgineus were measured in the field in southern France, near Montpellier (vouchers: Montferrier sur Lez, Chemin de la Meule, WGS84 $43.677667 \mathrm{~N}$, 3.861414 E, 9 Jul 2020, L. Varaldo, PI Nos. 041610-041619), while 17 individuals of $D$. caryophyllus var. inodorus were measured in the field in northern Italy, near Verona (vouchers: Busi di Avesa, Province of Verona, Veneto, $213 \mathrm{~m}$ a.s.l., WGS84 45.477858 N, 10.985452 E, 18 Jul 2020, L. Minuto, PI Nos. 041593-041609). This allowed a comparison between the lectotype specimens and recently collected, complete material.

Article history: Received: 15 Mar 2021 | returned for (first) revision: 20 May 2021 | (last) revision received: 17 Jun 2021 | accepted: 17 Jun 2021 | published online: 27 Aug 2021 | Associate Editor: James C. Lendemer | (C) 2021 The Authors.

TAXON published by John Wiley \& Sons Ltd on behalf of International Association for Plant Taxonomy.

This is an open access article under the terms of the Creative Commons Attribution-NonCommercial License, which permits use, distribution and reproduction in any medium, provided the original work is properly cited and is not used for commercial purposes. 


\section{- TYPIFICATION OF THE NAME DIANTHUS VIRGINEUS}

The protologue (Linnaeus, 1753: 412) consists of the nomen specificum legitimum "DIANTHUS caule subunifloro, corollis crenatis, squamis calycinis brevissimis, foliis subulatis" followed by the synonym "Caryophyllus sylvestris repens multiflorus" from Bauhin (1623: 209) and a reference to the Burser Herbarium "Burs. XI. 99". Under an unnamed var. $\beta$, Linnaeus listed "Tunica rupestris, folio caesio molli, flore carneo" from Dillenius (1732: 401, t. 298, fig. 385) as a further synonym. He also provided a more detailed description of this species, and its provenance was indicated as " $\mathrm{Habi-}$ tat Monspelii".

Jarvis (2007: 480) reported that the original material for this name consists of one specimen in the Burser Herbarium at UPS (Burser XI: 99; Fig. 1), one in the Linnaean Herbarium (LINN 581.25), and the illustration by Dillenius (1732: t. 298, fig. 385). The Linnaean Plant Name Typification Project database (http://www.nhm.ac.uk/our-science/data/linnaeantypification/) reports an illustration in the Herbarium Smith (LINN-HS 813.39) as further original material. However, the latter cannot be considered as such, since it is just an ink line drawing, obviously and explicitly based on the specimen “Burser XI: 99" at UPS V-174060 (Smith, 1794).

The Burser specimen at UPS (UPS V-174060) consists of a branch with two stalks bearing a single flower each and two dozen basal leaves. This specimen is labelled as "Caryophyllus Syl. repens multi florus Bauh.", and "Monspelii sponte" (= [growing] spontaneously at Montpellier). The specimen matches the diagnosis concerning the flower number ("caule subunifloro"), petals shape ("corollis crenatis"), epicalyx scales ("squamis calycinis brevissimis"), and leaf features ("foliis subulatis"). We also compared the specimen to a recent collection of 20 individuals from the Montpellier area (Table 1). The epicalyx, calyx and corolla of these plants are completely congruent with those of this original material and the protologue. The only feature not visible in the UPS specimen, due to the absence of flower buds, is the calyx shape just before anthesis, which is gradually tapering into an acuminate apex in the plants collected in the surroundings of Montpellier.

A second specimen was also found at UPS in the Burser Herbarium (Burser XI: 96; UPS V-174057 [digital image!]). While this specimen cannot be definitely considered original material due to the different polynomial reported on the label (“A. Caryophyllus Syl. humilis flore unico Bauh?”), it was also collected at Montpellier and identified as Dianthus virgineus by Juel (1936: 72). The specimen could potentially be a duplicate of the other Burser specimen discussed above. It consists of two individuals, both showing flowers in bud. The overall morphology of this specimen matches that of UPS V-174060, and the acuminate calyx shape before anthesis, which is not visible in that collection, is evident in UPS V-174057.

LINN 581.25 consists of a stalk with two flowers, one fully developed and the other in bud, with a dozen leaves at the base. At the bottom of the sheet there is the annotation
"9 plumarius virgineus", which makes questionable its status of original material (Jarvis, 2007). In addition, the petals in this specimen are deeply fringed, making it apparently more consistent with the protologue of Dianthus plumarius L. ("corollis multifidis"; Linnaeus, 1753: 411) than that of D. virgineus ("corollis crenatis"), and the annotated Species plantarum number 9 is that of D. plumarius. Accordingly, the specimen in LINN can be only doubtfully considered original material and also conflicts with the protologue.

The illustration by Dillenius (1732: t. 298, fig. 385) depicts a branch with six flowering stalks bearing one or two flowers each, and includes the polynomial "Tunica rupestris, folio

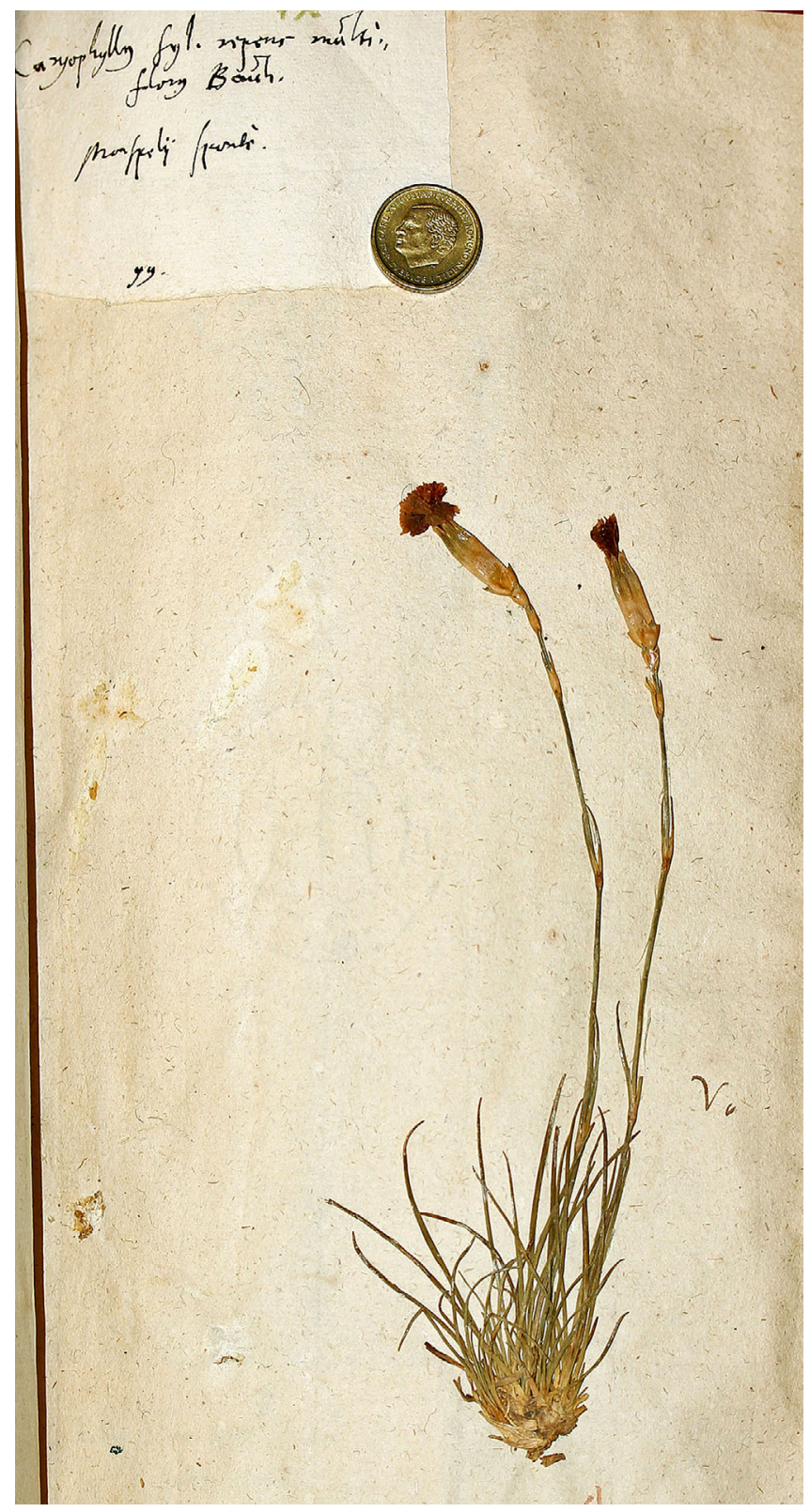

Fig. 1. "Caryophyllus Syl. repens multi florus Bauh., Monspelii sponte", Burser XI: 99 (UPS V-174060), lectotype of the name Dianthus virgineus $\mathrm{L}$. The coin is 10 SEK (20.5 $\mathrm{mm}$ in diameter). 
caesio molli, flore carneo". These plants, according to Dillenius (1732) grew spontaneously in Somerset, England. This illustration refers to the unnamed var. $\beta$ in the protologue, so it was not considered the typical form by Linnaeus (1753).

All the available original material, with the exception of the doubtful specimen in LINN, agrees with the current application of the Dianthus sylvestris complex (Tutin \& Walters, 1993; Bacchetta \& al., 2010). We designate Burser XI: 99 (UPS $\mathrm{V}-174060)$ as the lectotype, since it is in full agreement with the protologue, and extant specimens are preferred over illustrations in typification (Jarvis, 2007). Based on the morphology of the lectotype, the name $D$. virgineus clearly applies to a group of taxa referred to by some authors as $D$. sylvestris (e.g., Tutin \& Walters, 1993; Bacchetta \& al., 2010) and by others as D. caryophyllus sensu latissimo (e.g., Tison \& Foucault, 2014; Tison \& al., 2014). More specifically, within this group of taxa, the name $D$. virgineus applies to plants so far named D. sylvestris subsp. longicaulis (Ten.) Greuter \& Burdet (Tutin \& Walters, 1993), D. caryophyllus subsp. longicaulis (Ten.) Arcang. (Tison \& al., 2014), D. longicaulis Ten. (Bacchetta \& al., 2010), or D. godronianus Jord. (Tison \& Foucault, 2014; see also the interesting discussion by Godron, 1847). Given that the name D. caryophyllus applies to cultivated plants of unknown origin (see below), D. virgineus is the oldest name available that applies to the whole complex of native species, and the above-mentioned group of taxa should be referred to it, accordingly.

Dianthus virgineus L., Sp. Pl. 1: $412.1753 \equiv$ Tunica virginea (L.) Scop., Fl. Carniol., ed. 2, 1: 302.1771 D Dianthus rupestris Lam., Fl. Franç. 2: 536. 1779, nom. illeg. (Art. $52.1) \equiv$ Dianthus scheuchzeri Rchb., Fl. Germ. Excurs.: 811. 1832, nom. illeg. (Art. 52.1) 三 Dianthus caryophyllus var. virgineus (L.) Fiori, Fl. Italia 1(2): $379.1898-$ Lectotype (designated here): Caryophyllus Syl. repens multi florus Bauh., Monspelii sponte, Burser XI: 99 (UPS No. V-174060 [image!]).

For an image of the lectotype, see Fig. 1.

\section{- RELATED LINNAEAN NAMES AND THEIR RELATIONSHIP WITH DIANTHUS VIRGINEUS}

Dianthus caryophyllus var. caryophyllus. - According to Langen \& al. (1984), Dianthus caryophyllus, which is also the type of the generic name Dianthus, is homotypic with D. caryophyllus var. coronarius L. (published by Linnaeus, 1753: 410), and applies to cultivated plants of unknown origin. These plants are commonly regarded as closely related to, albeit clearly distinct on morphological grounds from, the D. sylvestris species complex (Tutin, 1964; Tutin \& Walters, 1993). Dianthus caryophyllus has glaucous, flat, wide (2-4 mm, even $1 \mathrm{~cm}$ in some cases), flaccid basal leaves and strongly fragrant, often sterile and polypetalous flowers, while D. sylvestris has green, convolute, narrow, wiry basal leaves and flowers not or slightly fragrant (Tutin, 1964; Pignatti, 1982; Tutin \& Walters, 1993; Brullo \& Guarino, 2017). Moreover, D. caryophyllus has been cultivated for hundreds of years for ornamental purposes, and complex hybridization events are involved in the origin of a high number of cultivars (Onozaki, 2018). Accordingly, we do not agree with the application of this name to wild plants commonly referred to the $D$. sylvestris species complex (Bacchetta \& al., 2010), as was done by Tison $\&$ al. (2014).

Dianthus caryophyllus L., Sp. Pl. 1: 410. $1753 \equiv$ Dianthus caryophyllus var. coronarius L., Sp. Pl. 1: 410. $1753 \equiv$ Dianthus coronarius (L.) Burm.f., Fl. Indica: 13. 1768, nom. illeg. (Art. 52.1) $\equiv$ Dianthus coronarius Lam., Fl. Franç. 2: 536. 1779, nom. illeg. (Art. 52.1) - Lectotype (designated by Ghafoor in Jafri \& El-Gadi, Fl. Libya 59: 104. 1978): Herb. Linnaeus No. 581.8 (LINN [image!]).

Dianthus caryophyllus var. inodorus. - Following the typification by Langen \& al. (1984), the name Dianthus caryophyllus var. inodorus L. (Linnaeus, 1753: 410) applies to plants from the surroundings of Verona (Veneto, northern Italy) (Séguier, 1745). Within D. caryophyllus and its varieties,

Table 1. Morphological comparison among the lectotypes of the names Dianthus virgineus and D. inodorus and topotypes from Montpellier (southern France) and Verona (northern Italy), respectively.

\begin{tabular}{|c|c|c|c|c|}
\hline & $\begin{array}{l}\text { D. virgineus } \\
\text { (lectotype) }\end{array}$ & $\begin{array}{l}\text { D. virgineus } \\
\text { (topotype) }\end{array}$ & $\begin{array}{l}\text { D. inodorus } \\
\text { (lectotype) }\end{array}$ & $\begin{array}{l}\text { D. inodorus } \\
\text { (topotype) }\end{array}$ \\
\hline $\begin{array}{l}\text { Innermost epicalyx scale } \\
\text { length/width ratio }\end{array}$ & 1.02 & $1.24 \pm 0.50$ & 1.99 & $1.31 \pm 0.27$ \\
\hline Calyx length/width ratio & 3.46 & $3.92 \pm 0.39$ & 6.50 & $5.99 \pm 2.17$ \\
\hline $\begin{array}{l}\text { Calyx shape before } \\
\text { anthesis }\end{array}$ & $\begin{array}{l}\text { Gradually tapering into an } \\
\text { acuminate apex* }\end{array}$ & $\begin{array}{l}\text { Gradually tapering into an } \\
\text { acuminate apex }\end{array}$ & $\begin{array}{l}\text { Abruptly tapering into } \\
\text { an acute apex }\end{array}$ & $\begin{array}{l}\text { Abruptly tapering into } \\
\text { an acute apex }\end{array}$ \\
\hline Corolla limb length $(\mathrm{cm})$ & 0.50 & $0.52 \pm 0.08$ & $\mathrm{n} / \mathrm{a}$ & $1.15 \pm 0.02$ \\
\hline Corolla limb width $(\mathrm{cm})$ & 0.47 & $0.47 \pm 0.07$ & $\mathrm{n} / \mathrm{a}$ & $0.90 \pm 0.02$ \\
\hline $\begin{array}{l}\text { Corolla limb length/width } \\
\text { ratio }\end{array}$ & 1.06 & $1.12 \pm 0.14$ & 1.21 & $1.29 \pm 0.17$ \\
\hline
\end{tabular}

Mean values and standard deviation are reported for plants collected by us. * = from the specimen UPS V-174057. 
D. caryophyllus var. inodorus is the only one that applies to wild plants (Langen \& al., 1984), representing a potential heterotypic synonym of $D$. virgineus. However, the analysis of the morphological features that can be deduced from the lectotype and the original description (Séguier, 1745: 435437), along with those measured on 17 plants recently collected in a topotypical population (Table 1), allow us to highlight several morphological differences with respect to $D$. virgineus. For instance, the calyx, just before anthesis, is abruptly tapering into an acute apex in $D$. inodorus. In addition, calyces, epicalyx scales, and petal limbs are more slender.

The above data do not support the conspecificity of Dianthus inodorus with $D$. virgineus. In fact, although both clearly fall within the variability of the $D$. sylvestris species complex (Bacchetta \& al., 2010), D. virgineus applies to plants so far named $D$. longicaulis or $D$. godronianus (see above), while $D$. inodorus could represent a heterotypic synonym of D. sylvestris Wulfen s.str. (Tutin, 1964; Pignatti, 1982; Tutin \& Walters, 1993; Bacchetta \& al., 2010; Brullo \& Guarino, 2017). Nonetheless, the exact identity of $D$. caryophyllus

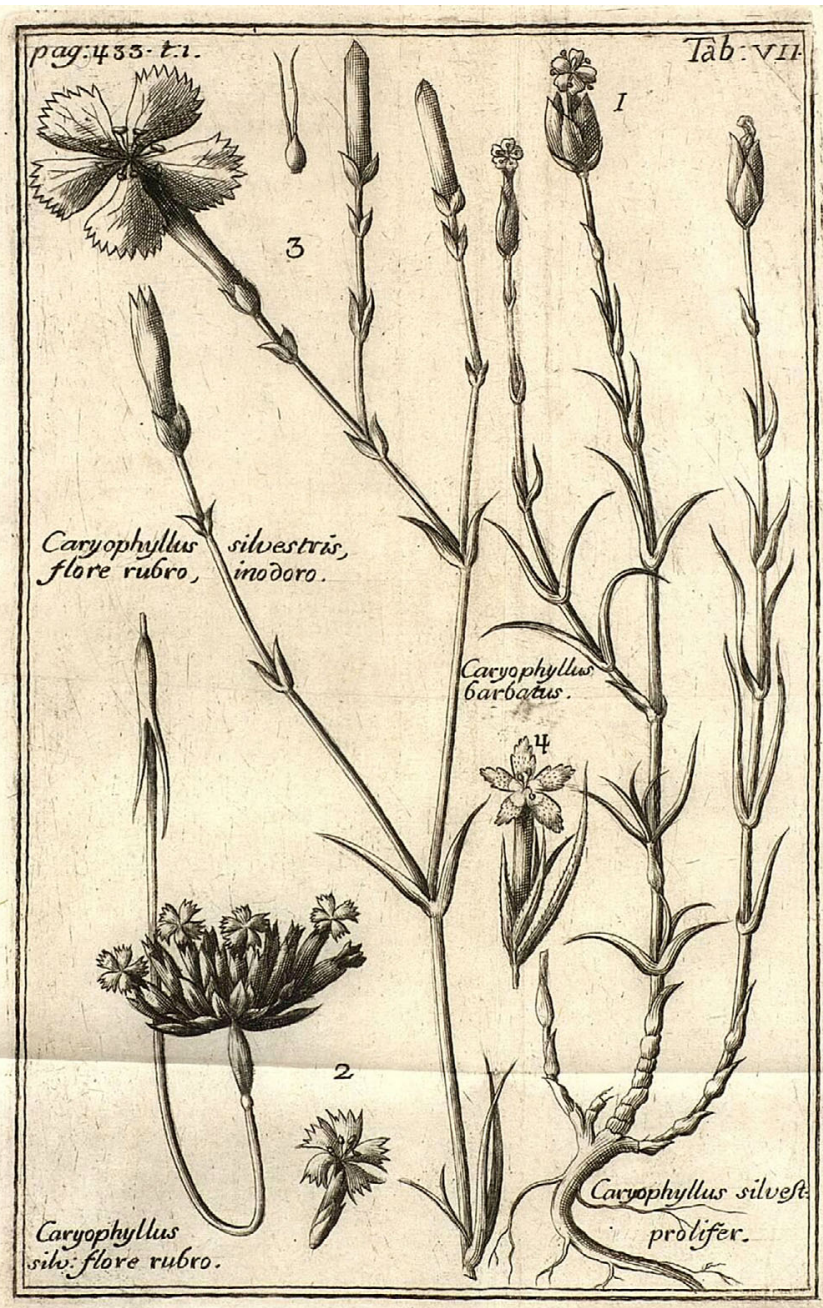

Fig. 2. Illustration of "Caryophyllus silvestris, flore rubro, inodoro" in Séguier (1745: 433, t. VII, fig. 3), lectotype of the name Dianthus caryophyllus var. inodorus $\mathrm{L}$. var. inodorus as a synonym of $D$. sylvestris (a species described from eastern Alps) has been questioned by multiple authors (Pignatti, 1982; Langen \& al., 1984, Brullo \& Guarino, 2019). Further comparative studies are currently underway to clarify the taxonomic relationships among the taxa belonging to the $D$. virgineus species complex, including $D$. inodorus (L.) Gaertn. and D. sylvestris Wulfen.

Dianthus caryophyllus var. inodorus L., Sp. Pl. 1: 410. 1753 $\equiv$ Dianthus inodorus (L.) Gaertn., Fruct. Sem. Pl. 2: 227 , t. 129, fig. 13. 1790 - Lectotype (designated by Langen \& al. in Taxon 33: 719. 1984): [illustration] "Caryophyllus silvestris, flore rubro, inodoro" in Séguier, Pl. Veron. 1: t. VII, fig. 3. 1745.

For an image of the lectotype, see Fig. 2.

\section{AUTHOR CONTRIBUTIONS}

LP and GA made preliminary nomenclatural research, GD and GB drafted the manuscript, LM and LV collected and analysed topotypical materials of Dianthus virgineus and D. inodorus, DG first noticed morphological differences among the two taxa. All authors contributed and reviewed advanced versions of the manuscript. — GD, https://orcid.org/ 0000-0003-4184-398X; GA, https://orcid.org/0000-0001-5790-3516; GB, https://orcid.org/0000-0002-6345-3117; DG, https://orcid.org/00000003-4677-3730; LM, https://orcid.org/0000-0002-1582-3806; LP, https://orcid.org/0000-0001-9008-273X

\section{ACKNOWLEDGEMENTS}

We thank the curator of UPS (M. Hjertson) for providing scanned specimens from Burser Herbarium. This work was supported by the Progetto di Ricerca di Rilevante Interesse Nazionale (PRIN) "PLAN.T.S. 2.0 - towards a renaissance of PLANt Taxonomy and Systematics" led by the University of Pisa, under the grant number 2017JW4HZK (Principal Investigator: Lorenzo Peruzzi). Open Access Funding provided by Universita degli Studi di Pisa within the CRUI-CARE Agreement.

\section{口 LITERATURE CITED}

Bacchetta, G., Brullo, S., Casti, M. \& Giusso del Galdo, G.P. 2010. Taxonomic revision of the Dianthus sylvestris group (Caryophyllaceae) in central-southern Italy, Sicily and Sardinia. Nordic J. Bot. 28: 137-173. https://doi.org/10.1111/j.1756-1051.2009. 00459.x

Bauhin, C. 1623. Pinax theatri botanici. Basileae Helvet. [Basel]: sumptibus \& typis Ludovici Regis. https://doi.org/10.5962/ bhl.title.712

Brullo, S. \& Guarino, R. 2017. Complesso di Dianthus sylvestris. Pp. 200-205 in: Pignatti, S. (ed.), Flora d'Italia, 2nd ed., vol. 2. Milan: New Business Media.

Brullo, S. \& Guarino, R. 2019. Dianthus L. Pp. 77-81 in: Pignatti, S. (ed.), Flora d'Italia, 2nd ed., vol. 4. Milan: New Business Media.

Dillenius, J.J. 1732. Hortus Elthamensis, t. alter. Londini [London]: sumptibus auctoris. https://bibdigital.rjb.csic.es/idurl/1/11970

Giacò, A., Astuti, G. \& Peruzzi, L. 2021. Typification and nomenclature of the names in the Santolina chamaecyparissus species complex (Asteraceae). Taxon 70(1): 189-201. https://doi.org/10. 1002/tax.12429 
Godron, M. 1847. Observations sur le Dianthus virgineus de Linné. Mém. Soc. Roy. Sci. Nancy 1846: 1-16.

Jafri, S.M.H. \& El-Gadi, A. 1978. Flora of Libya, vol. 59. Tripoli: Al-Faateh University.

Jarvis, C. 2007. Order out of chaos: Linnaean plant names and their types. London: Linnean Society of London with the Natural History Museum. https://doi.org/10.3366/e0260954108000442

Juel, H.O. 1936. Joachim Bursers Hortus siccus. Symb. Bot. Upsal. 2(1): 1-187.

Langen, F.R. de, Oost, E.H. \& Jarvis, C.E. 1984. Lectotypification of Dianthus caryophyllus L. and D. chinensis L. (Caryophyllaceae). Taxon 33: 716-724. https://doi.org/10.2307/1220794

Linnaeus, C. 1753. Species plantarum, vol. 1. Holmiae [Stockholm]: impensis Laurentii Salvii. https://doi.org/10.5962/bhl.title.669

Mabberley, D.J. 2008. Mabberley's Plant-Book: A portable dictionary of plants, their classifications, and uses, 3rd ed. Cambridge: Cambridge University Press.

Marhold, K. 2011+. Caryophyllaceae. In: Euro+Med Plantbase - The information resource for Euro-Mediterranean plant diversity. Published at http://www.europlusmed.org (accessed 15 Mar 2021).

Onozaki, T. 2018. Dianthus. Pp. 349-381 in: Van Huylenbroeck, J. (ed.), Ornamental crops. Handbook of Plant Breeding 11. Springer International Publishing. https://doi.org/10.1007/978-3319-90698-0_15

Pignatti, S. 1982. Flora d'Italia, 1st ed., vol. 1. Bologna: Edagricole.

Séguier, J.F. 1745. Plantae Veronenses, vol. 1. Veronae [Verona]: Typis Seminarii. https://bibdigital.rjb.csic.es/idurl/1/13684

Smith, E. 1794. Remarks on the genus Dianthus. Trans. Linn. Soc. 2: 292-304. https://doi.org/10.1111/j.1096-3642.1794.tb00262.x
Tison, J.-M. \& Foucault, B. de 2014. Flora Gallica: Flore de France. Mèze: Biotope.

Tison, J.-M., Jauzein, P. \& Michaud, H. 2014. Flore de la France méditerranéenne continentale. Turriers: Naturalia Publications; Porquerolles: Conservatoire botanique national méditerranéen de Porquerolles.

Turland, N.J., Wiersema, J.H., Barrie, F.R., Greuter, W., Hawksworth, D.L., Herendeen, P.S., Knapp, S., Kusber, W.-H., Li, D.-Z., Marhold, K., May, T.W., McNeill, J., Monro, A.M., Prado, J., Price, M.J. \& Smith, G.F. (eds.) 2019. International Code of Nomenclature for algae, fungi, and plants (Shenzhen Code) adopted by the Nineteenth International Botanical Congress Shenzhen, China. Regnum Vegetabile 159. Glashütten: Koeltz Botanical Books. https://doi.org/10.12705/Code.2018

Tutin, T.G. 1964. Dianthus L. Pp. 188-204 in: Tutin, T.G., Burges, N.A., Chater, A.O., Edmondson, J.R., Heywood, V.H., Moore, D.M., Valentine, D.H., Walters, S.M. \& Webb D.A. (eds.), Flora Europaea, vol. 1. Cambridge: Cambridge University Press.

Tutin, T.G. \& Walters, S.M. 1993. Dianthus L. Pp. 227-246 in: Tutin, T.G., Burges, N.A., Chater, A.O., Edmondson, J.R., Heywood, V.H., Moore, D.M., Valentine, D.H., Walters, S.M. \& Webb, D.A. (eds.), Flora Europaea, 2nd ed., vol. 1. Cambridge: Cambridge University Press.

WFO 2021. World Flora Online. Published on the Internet; http:// www.worldfloraonline.org (accessed 15 Mar 2021).

Wulfen, F.X. 1786. Plantae rariores carinthiacae. Pp. 237-239 in: Jacquin, N.J., Collectanea ad botanicam, chemiam, et historiam naturalem spectantia, vol. 1. Vindobonae [Vienna]: ex officina Wappleriana. https://bibdigital.rjb.csic.es/idurl/1/11956 